\title{
The role of trans obturator tape as a surgical procedure for female stress urinary incontinence and its impact on quality of life in Jammu region
}

\author{
Sapna Puri, Manisha Kohli*
}

Department of Obstetrics and Gynecology, Acharya Shri Chander College of Medical Sciences and Hospital, Jammu, Jammu and Kashmir, India

Received: 23 September 2019

Accepted: 06 November 2019

\section{*Correspondence:}

Dr. Manisha Kohli,

E-mail: dr_manisha09@rediffmail.com

Copyright: (c) the author(s), publisher and licensee Medip Academy. This is an open-access article distributed under the terms of the Creative Commons Attribution Non-Commercial License, which permits unrestricted non-commercial use, distribution, and reproduction in any medium, provided the original work is properly cited.

\begin{abstract}
Background: Stress incontinence is one of the most common but debilitating health issue among women. It has a detrimental effect on overall health and quality of life of women. Trans obturator tape (TOT) has emerged as a promising treatment modality. The aim of present study was to assess the usefulness of TOT in terms of change in quality of life of stress incontinence patients.

Methods: The study was performed at Department of Obstetrics and Gynecology, Acharya Shri Chandler of Medical Sciences (ASCOMS), Jammu. A total of 50 symptomatic women were enrolled in the study and underwent TOT procedure using outside-in technique. The quality of life of women was assessed at enrolment and 12 months after the procedure using King's Health Questionnaire (KHQ). Change in QOL was assessed using paired ' $t$ '-test.

Results: After 12 months follow-up, a total of 27 (54\%) patients were entirely symptom free. As compared to pretreatment QOL assessment on KHQ for general health/incontinence impact, quality of life and symptom scores a \% decline of $73.2 \%, 79.8 \%$ and $78.4 \%$ was observed. For all the three parts, the change in scores was significant statistically. No other complications and side effects were reported.

Conclusions: TOT is a useful procedure which provided symptomatic relief as well as QOL enhancement.
\end{abstract}

Keywords: King's health questionnaire, Quality of life, Stress incontinence, Symptom score, Trans obturator tape

\section{INTRODUCTION}

Involuntary loss or leakage of urine is known as urinary incontinence. It is highly prevalent among women. ${ }^{1}$ Urinary incontinence could be described to be of two major types - stress urinary incontinence, which is defined as "the involuntary loss of urine on effort or physical exertion or on sneezing or coughing"; and urge urinary incontinence - in which urine leaks in association with a sudden compelling desire to void. ${ }^{2}$ Another type called mixed type is recognized when both stress and urinary incontinence are present together. Urinary incontinence affects nearly $20-30 \%$ women during their lifetime, and almost half of the affected women have stress urinary incontinence. ${ }^{3,4}$ Untreated stress incontinence has a strong psychosocial and financial impact that affects the quality of life of affected women. ${ }^{5,6}$

Stress incontinence is a cause of embarrassment, social stigma, personal guilt, fear of unhygienic conditions and of carrying unnecessary burden. Hence, it should be addressed urgently with essential therapeutic interventions. A wide array of treatment options is 
available for symptomatic patients with stress incontinence that include, both surgical as well as nonsurgical modalities. Behavioural therapy, pelvic floor muscle training, electrical stimulation and vaginal cones are some of the non-surgical modalities apart from option of use of some continence devices, pharmacological and hormonal treatment. On the other hand, as many as 200 surgical treatment options are available for management of stress incontinence. ${ }^{7}$

Amidst various surgical treatment options available, transobturator tape (TOT) has emerged as one of the most popular and successful treatment modalities. In this procedure, TOT which is a polyester ribbon, is placed through small incisions placed in the groins and in the vagina under the urethra. It is a simple procedure that can be learnt in short time, takes short operative time and has a high success rate. ${ }^{8}$

As stress urinary incontinence has a strong impact on quality of life, hence the success of a procedure can be gauged by studying change in quality of life following surgical procedure over a substantial period of time. Hence, the present study was carried out to study the role of TOT as a surgical procedure for female stress incontinence and to study its impact on the quality of life of affected women at a tertiary care centre in Jammu, India.

\section{METHODS}

A total of 50 symptomatic women with stress incontinence attending the gynaecological clinic of ASCOMS, Jammu (India) were enrolled in the study. All the patients underwent clinical evaluation and urodynamic studies and those with mixed incontinence were excluded from the study. Those patients with neurological disorders affecting urinary function, active urinary tract infection, significant uterovaginal prolapse requiring different surgical approach and urge continence were also excluded from the study.

Prior to procedure, demographic details and clinical history of patients was recorded. They subsequently underwent quality of life assessment using King's Health Questionnaire (KHQ). ${ }^{9}$ Scoring for different domains/items was done in accordance with the criteria suggested by Hebber et al. ${ }^{10}$

All the women underwent TOT placement using standard outside-in surgical technique. During post-operative period they were evaluated for presence of any side effect. All the women were followed up at 3 months, 6 months and 12 months intervals. Final QoL assessment was made at 12 months.

\section{Statistical analysis}

Data collected was analyzed using Statistical package for social sciences version 21.0. Paired ' $t$ '-test was used to compare the data. A 'p' value less than 0.05 was considered as significant.

\section{RESULTS}

Age of women ranged from 35 to 66 years. Majority of women $(64 \%)$ were in age range 41 to 60 years. Mean age of women was $51.74 \pm 9.28$ years. BMI of women ranged from 17.5 to $39.5 \mathrm{~kg} / \mathrm{m}^{2}$. Majority of women had BMI > $30 \mathrm{~kg} / \mathrm{m}^{2}(54 \%)$. Mean BMI of women was $30.27 \pm 6.33 \mathrm{~kg} / \mathrm{m}^{2}$. Majority of women $(80 \%)$ were housewives, only $10(20 \%)$ were working women. Almost two-third (66\%) belonged to middle class, a total of $14(28 \%)$ were from lower class and only $3(6 \%)$ were from upper socioeconomic class. Majority of women (70\%) did not report of any significant comorbidity. However, 15 (30\%) reported comorbidities. There were 5 $(10 \%)$ women each having diabetes and hypertension respectively, a total of $2(4 \%)$ each had anemia and hypertension with diabetes while $1(2 \%)$ patient reported of asthma (Table 1).

Table 1: General profile and characteristics of study population $(\mathbf{n}=\mathbf{5 0})$.

\begin{tabular}{|c|c|c|}
\hline Sr. No. & Characteristic & Statistic \\
\hline \multirow{6}{*}{1.} & Age & \\
\hline & 31-40 Years & $7(14.0 \%)$ \\
\hline & 41-50 Years & $16(32.0 \%)$ \\
\hline & 51-60 Years & $16(32.0 \%)$ \\
\hline & $61-70$ Years & $11(22.0 \%)$ \\
\hline & $\begin{array}{l}\text { Mean age } \pm \text { SD (range) in } \\
\text { years }\end{array}$ & $51.74 \pm 9.28(35-66)$ \\
\hline \multirow{6}{*}{2.} & Body mass index (BMI) & \\
\hline & $<18.5 \mathrm{~kg} / \mathrm{m}^{2}$ & $3(6.0 \%)$ \\
\hline & $18.5-24.9 \mathrm{~kg} / \mathrm{m}^{2}$ & $9(18.0 \%)$ \\
\hline & $25.0-29.9 \mathrm{~kg} / \mathrm{m}^{2}$ & $11(22.0 \%)$ \\
\hline & $\geq 30.0 \mathrm{~kg} / \mathrm{m}^{2}$ & $27(54.0 \%)$ \\
\hline & $\begin{array}{l}\text { Mean BMI } \pm \text { SD (range) } \\
\mathrm{kg} / \mathrm{m}^{2}\end{array}$ & $\begin{array}{l}30.27 \pm 6.33(17.5- \\
39.5)\end{array}$ \\
\hline \multirow{3}{*}{3.} & Working Status & \\
\hline & Housewife & $40(80.0 \%)$ \\
\hline & Working & $10(20.0 \%)$ \\
\hline \multirow{4}{*}{4.} & Socioeconomic Status & \\
\hline & Lower & $14(28.0 \%)$ \\
\hline & Middle & $33(66.0 \%)$ \\
\hline & Upper & $3(6.0 \%)$ \\
\hline \multirow{7}{*}{5.} & Comorbidities & \\
\hline & No comorbidity & $35(70.0 \%)$ \\
\hline & Anemia & $2(4.0 \%)$ \\
\hline & Diabetes & $5(10.0 \%)$ \\
\hline & Hypertension & $5(10.0 \%)$ \\
\hline & Diabetes + hypertension & $2(4.0 \%)$ \\
\hline & Asthma & $1(2.0 \%)$ \\
\hline
\end{tabular}

Pre-treatment general health/incontinence impact, quality of life and symptom scores (Parts 1,2 and 3 of King's Health Questionnaire) were 123.00 \pm 48.47 , 
$247.94 \pm 115.08$ and $16.50 \pm 6.25$ respectively which declined to reach at $32.99 \pm 36.76,50.01 \pm 66.27$ and $3.56 \pm 4.78$ respectively at follow-up, thus showing \% decline of $73.2 \%, 79.8 \%$ and $78.4 \%$. For all the three parts, the change in scores was significant statistically ( $\mathrm{p}$ $<0.001$ ) (Table 2).

Table 2: Pre- and post-TOT QOL scores for general health/incontinence impact, quality of life and symptom scores (King's Health Questionnaire).

\begin{tabular}{|lllll|}
\hline $\begin{array}{l}\text { Sr. } \\
\text { No. }\end{array}$ Domain & $\begin{array}{l}\text { Pre-treatment } \\
(\text { Mean } \pm \text { SD) }\end{array}$ & $\begin{array}{l}\text { Post-treatment } \\
\text { (Mean } \pm \text { SD) }\end{array}$ & $\begin{array}{l}\text { Significance of difference } \\
\text { (Paired ' } t \text { '-test) }\end{array}$ \\
\hline 1. & $\begin{array}{l}\text { General health/ incontinence impact } \\
\text { (Part 1) }\end{array}$ & $123.00 \pm 48.47$ & $32.99 \pm 36.76$ & ' $\mathrm{t}$ ' $=15.36 ; \mathrm{p}<0.001$ \\
\hline 2. & $\begin{array}{l}\text { Quality of life } \\
\text { (Part 2) }\end{array}$ & $247.94 \pm 115.08$ & $50.01 \pm 66.27$ & ' $\mathrm{t}$ ' $=16.45 ; \mathrm{p}<0.001$ \\
\hline 3. & $\begin{array}{l}\text { Symptom score } \\
\text { (Part 3) }\end{array}$ & $16.50 \pm 6.25$ & $3.56 \pm 4.78$ & ' $\mathrm{t}$ ' $=24.84 ; \mathrm{p}<0.001$ \\
\hline
\end{tabular}

Table 3: Itemized pre- and post-TOT QOL scores among women with stress incontinence.

\begin{tabular}{|c|c|c|c|c|}
\hline Sr. No. & Item & $\begin{array}{l}\text { Pre-treatment } \\
(\text { Mean } \pm \text { SD) }\end{array}$ & $\begin{array}{l}\text { Post-treatment } \\
(\text { Mean } \pm \text { SD) }\end{array}$ & $\begin{array}{l}\text { Significance of difference } \\
\text { (Paired ' } t \text { '-test) }\end{array}$ \\
\hline \multicolumn{5}{|l|}{ Part 1} \\
\hline 1. & General health perception & $53.00 \pm 26.07$ & $17.00 \pm 21.09$ & $' t '=11.83 ; p<0.001$ \\
\hline 2. & Incontinence impact & $70.00 \pm 27.16$ & $15.99 \pm 19.39$ & $' t '=15.22 ; p<0.001$ \\
\hline \multicolumn{5}{|l|}{ Part 2} \\
\hline 1. & Role limitations & $41.67 \pm 31.28$ & $10.00 \pm 16.50$ & $' t '=9.11 ; p<0.001$ \\
\hline 2. & Physical limitations & $19.34 \pm 22.43$ & $3.34 \pm 10.65$ & $' t '=6.47 ; p<0.001$ \\
\hline 3. & Social limitations & $41.68 \pm 27.41$ & $8.16 \pm 15.46$ & $' t^{\prime}=11.63 ; p<0.001$ \\
\hline 4. & Personal relationships & $30.34 \pm 25.13$ & $5.84 \pm 10.14$ & $' t '=7.42 ; p<0.001$ \\
\hline 5. & Emotions & $44.74 \pm 24.04$ & $8.99 \pm 11.91$ & $' t '=12.31 ; p<0.001$ \\
\hline 6. & Sleep/energy & $33.67 \pm 24.17$ & $7.00 \pm 13.08$ & $' \mathrm{t} '=9.75 ; \mathrm{p}<0.001$ \\
\hline 7. & Severity measures & $34.50 \pm 18.96$ & $6.67 \pm 11.17$ & $' t '=13.28 ; p<0.001$ \\
\hline \multicolumn{5}{|l|}{ Part 3} \\
\hline 1. & Symptom score & $16.50 \pm 6.25$ & $3.56 \pm 4.78$ & $' \mathrm{t} '=24.84 ; \mathrm{p}<0.001$ \\
\hline \multicolumn{3}{|c|}{ Overall symptom free (Score 0$)$} & $27(54 \%)$ & \\
\hline
\end{tabular}

On itemized evaluation, pre-treatment general health perception and incontinence impact scores were $53.00 \pm 26.07$ and $70.00 \pm 27.16$ respectively which declined to reach at $17.00 \pm 21.09$ and $15.99 \pm 19.39$ respectively at follow-up, thus showing a $\%$ decline of $67.9 \%$ and $77.1 \%$ respectively. For both the items, the change was significant statistically $(\mathrm{p}<0.001)$ (Table 3 , Part 1).

For items under part 2 of KHQ, minimum pre-treatment score was observed for physical limitations (19.34 \pm 22.43$)$ while maximum was observed for item Emotions (44.74 \pm 24.04$)$. Following treatment, mean scores ranged from $3.34 \pm 10.65$ (physical limitation) to $10.00 \pm 16.50$ (role limitations). For all the items the decline was significant statistically too. For symptom score too, there was a significant decline at follow-up. A total of $27(54 \%)$ women were entirely symptom free (Table 3; Part 2 and 3).
No other side effect or complication was reported.

\section{DISCUSSION}

In present study, age group 41 to 60 years was most affected. Though prevalence of urinary incontinence of any type is reportedly high in older women yet stress incontinence is relatively more common in younger women as reflected in present study. Older women general have higher prevalence of urge incontinence. ${ }^{11}$ In present study higher BMI emerged as a key presenting factor. Obesity in fact is another recognized risk factor for urinary incontinence. ${ }^{11}$ Majority of women in present study were housewives and belonged to middle class. As such no association of stress incontinence with occupation or socioeconomic class has been reported and these findings in general reflect the profile of women visiting our facility. However, the higher prevalence of housewives and middle-class women could be held responsible for delay in seeking treatment in earlier and 
more mild stages and thus necessitating the surgical intervention. In present study, a total of 15 (30\%) women had coexisting morbidities with diabetes and hypertension occupying the major proportions. Diabetes and hypertension are also recognized risk factors for urinary incontinence and the findings of present study also endorse that. ${ }^{11}$ As far as demographic, anthropometric and comorbidity profile of cases in present study is concerned it is similar to that reported by Guin et al who also highlighted age group 40-60 years, higher BMI, and associated comorbidities to be common characteristics of the patients. $^{12}$

In present study, pre-treatment general health/incontinence impact, quality of life and symptom scores (Parts 1, 2 and 3 of King's Health Questionnaire) were $123.00 \pm 48.47,247.94 \pm 115.08$ and $16.50 \pm 6.25$ respectively which declined to reach at $32.99 \pm 36.76$, $50.01 \pm 66.27$ and $3.56 \pm 4.78$ respectively at follow-up, thus showing $\%$ decline of $73.2 \%, 79.8 \%$ and $78.4 \%$. A total of $27(54 \%)$ were entirely symptom free at one-year follow-up. These are promising findings, various studies having different durations of follow-up have shown improvement in quality of life of women undergoing TOT placement. Celada et al, in a study that included a follow-up period of 10 years showed cure and improvement in QoL in $85.7 \%$ and $92.9 \%$ women respectively. ${ }^{13}$ As far as improvement in QoL is concerned, in present study all the women showed reduction in QoL scores in all the domains of KHQ, thus showing that there was improvement in QoL of all the women. With respect to magnitude of improvement in quality of life of women too, the present study showed a promising response with improvements ranging from $73.2 \%$ to $79.8 \%$ in different domains of KHQ. In a preand post-operative assessment of QoL, Paul et al, witnessed 90\% reduction in QoL scores. ${ }^{14}$ Aygul et al, in another study that included follow-up range of 12 to 36 months also reported nearly $75 \%$ to $80 \%$ reduction in symptomatic quality of life. ${ }^{15}$ Some other workers who also used KHQ for assessment of quality of life of women undergoing TOT placement also reported high range of improvement over different follow up times, Jacob et al, at six months follow up reported improvement in quality of life of $86.66 \%$ women and a reduction of $74.6 \%$ in the Part 2 domain of KHQ ${ }^{16}$ Jose et al, who questioned patients with a follow-up range of 7 to 29 months reported a median post-operative KHQ score of 66.66, which is higher than the post-operative KHQ score of patients of our study and could be attributable to difference in population and follow-up period. ${ }^{17}$ Nevertheless, almost all the studies have reported that TOT placement brings up to a significantly measurable qualitative change in quality of life of affected patients as observed in present study.

\section{CONCLUSION}

In present study, preoperatively, emotions were found to be most adversely affected among stress incontinence patients, thereby showing that stress incontinence had a huge psychological and emotional burden. On the other hand, postoperatively physical limitation was the domain with least affect while role limitation was the most affected item. These findings in turn show that following treatment, there is need for psychological counselling of the women to enable them to generate confidence regarding the expansion of their roles which were otherwise affected owing to burden of stress incontinence.

The present study showed that KHQ can be a useful measure to evaluate the outcome of TOT surgery over different periods of times, both for quality of life as well as symptomatic burden of stress incontinence. Further studies over variable periods of follow-up are recommended.

\section{Funding: No funding sources}

Conflict of interest: None declared

Ethical approval: The study was approved by the Institutional Ethics Committee

\section{REFERENCES}

1. Aoki Y, Brown HW, Brubaker L, Cornu JN, Daly JO, Cartwright R. Urinary incontinence in women. Nat Rev Dis Primers. 2017;3:17042.

2. Haylen BT, de Ridder D, Freeman RM, Swift SE, Berghmans B, Lee J. An International urogynecological association (IUGA)/International continence society (ICS) joint report on the terminology for female pelvic floor dysfunction. Neurourol Urodyn. 2010;29:4-20.

3. Hampel C, Weinhold D, Benken N Eggersmann C, Thuroff JW. Definition of overactive bladder and epidemiology of urinary incontinence. Urol. 1997;50:4.

4. Hampel C, Artibani W, Espuña Pons M, Haab F, Jackson S, Romero J, et al. Understanding the burden of stress urinary incontinence in Europe: A qualitative review of the literature. Eur Urol. 2004;46:15.

5. Tennstedt SL, Fitzgerald MP, Nager CW, Xu Y, Zimmern P, Kraus S, et al. Quality of life in women with stress urinary incontinence. Int Urogynecol $\mathbf{J}$ Pelvic Floor Dysfunct. 2007;18(5):543-9.

6. Ganapathy $\mathrm{T}$. Impact of urinary incontinence on quality of life among rural women. Muller J Med Sci Res. 2018;9:71-7.

7. Rovner ES, Wein AJ. Treatment options for stress urinary incontinence. Rev Urol. 2004;6 Suppl 3(Suppl 3):S29-S47.

8. Magon N, Chopra SV. Transobturator tape in treatment of stress urinary incontinence: it is time for a new gold standard. $\mathrm{N}$ Am J Med Sci. 2012;4(5):226-30.

9. Reese PR, Pleil AM, Okano GJ, Kelleher CJ. Multinational study of reliability and validity of the King's Health questionnaire in patients with 
overactive bladder. Qual Life Res. 2003;12(4):42742.

10. Hebbar S, Pandey H, Chawla A. Understanding King's Health Questionnaire (KHQ) in assessment of female urinary incontinence. Int $\mathbf{J}$ Res Med Sci. 2015;3(3):531-8.

11. Luber KM. The definition, prevalence, and risk factors for stress urinary incontinence. Rev Urol. 2004;6 Suppl 3(Suppl 3):S3-S9.

12. Guin G, Choudhary A, Dadhich R. Prevalence of stress urinary incontinence and its associated risk factors amongst females attending tertiary referral centre. Int J Reprod Contracept Obstet Gynecol. 2018;7(6):211-9.

13. Celada P, Cañete P, Ortiz Murillo E, Tarín JJ, Cano A. Effectiveness and quality of life 10 years after transobturator suburethral tape surgery for stress urinary incontinence. J Obstet Gynaecol Res. 2018;44(3):518-23

14. Paul F, Joce AP, Giridhar A, Mampatta J, Shetty S, Bhat S. Impact of transobturator tape procedure on quality of life in female stress urinary incontinence. Int J Anat Radiol Surg. 2017;6(1):SO06-9.
15. Aygül C, Özyurt R, Şık BA, Kumbasar S. Evaluation of the efficacy of transobturator tape surgery in the treatment of stress urinary incontinence using urodynamics and questionnaires. Turk $\mathbf{J}$ Obstet Gynecol. 2016;13(4):172-7.

16. Jacob KJ, Jayaprakash M, Cherian A. Quality of life assessment in women with stress urinary incontinence following Trans Obturator Tape (TOT) insertion: a prospective study. Int $\mathbf{J}$ Reprod Contracept Obstet Gynecol. 2017;6(10):4508-10.

17. Jose D, Zoff F, Modotti CG. An evaluation of the outcome and quality of life after TOT-surgery. Int $\mathbf{J}$ Obstet Gynaecol. 2016;4(1):117-22.

Cite this article as: Puri S, Kohli M. The role of trans obturator tape as a surgical procedure for female stress urinary incontinence and its impact on quality of life in Jammu region. Int J Reprod Contracept Obstet Gynecol 2019;8:4975-9. 